\title{
Rysslands hanterande av sin intressesfär i Sydkaukasien
}

\author{
Jakob Hedenskog \\ Totalförsvarets forskningsinstitut (FOI), Sverige
}

\begin{abstract}
Russia's operationalization of a sphere of interest in the South Caucasus A central foreign policy objective of Russia is to maintain an exclusive sphere of interest in its post-Soviet neighbourhood. This article analyses how Russia employs a combination of political and military instruments in operationalizing its perceived sphere of interest in the still conflict-ridden South Caucasus. Russia is the only external power in the region to have military bases there, and is the only one seemingly ready to undertake military action. At present, Russia appears satisfied with the status quo in the South Caucasus. The unresolved conflicts in Abkhazia, South Ossetia and Nagorno-Karabakh are therefore unlikely to be resolved in the near future. Unresolved conflicts suit Russia's objectives. Russian military bases in Georgia and Armenia provide Moscow with both a key lever against Tbilisi and Yerevan and a structural advantage for potential Russian military operations in the region. Russia's military posture in the Caucasus is relevant to the potential for large-scale conflict in the Southern war theatre, including the wider Middle East, and not just local conflicts in the Caucasus.
\end{abstract}

Keywords: Armenia, Azerbaijan, Caucasus, Georgia, Russia, sphere of interest

Rysk utrikespolitik präglas av två övergripande och långsiktiga mål. Det första är att Ryssland ska bli erkänt som en stormakt i världspolitiken i paritet med USA. Enligt den nu gällande nationella säkerhetsstrategin är ett av Rysslands långsiktiga strategiska intressen att konsolidera sin "status som en ledande världsmakt, vars agerande är menat att bibehålla strategisk stabilitet och ömsesidigt fördelaktigt partnerskap i en polycentrisk värld» (Rysslands säkerhetsråd, 2015). På ett liknande sätt talar Utrikespolitiska konceptet om landets behov av att konsolidera sin status som »ett inflytandecenter i dagens värld» (Rysslands utrikesministerium, 2016).

Det andra målet är att skapa en unik intressesfär i det postsovjetiska området och hindra inflytande från väst, främst USA, genom att dessa länder inte blir medlemmar i Nato eller EU (Hedenskog et al., 2018). På den globala nivån eftersträvar Ryssland en position som ett oberoende maktcentrum bland flera i den multipolära världsordningen och kräver att få sin röst hörd i alla viktiga globala frågor. I det

\footnotetext{
^Kontaktinformasjon: Jakob Hedenskog, e-post: jakob.hedenskog@foi.se 
postsovjetiska området däremot har Moskva hegemoniska ambitioner. Andra stormakter tillåts agera, men inte på ett sätt som utmanar vad den ryska politiska ledningen anser är Rysslands vitala intressen. Kontroll över en egen intressesfär anses vara en nödvändig förutsättning för att agera som en global makt. Således är dessa två utrikespolitiska mål tätt sammanflätade. Ryssland har visat sig mycket beslutsamt att gå långt för att uppnå dessa mål, inklusive att kränka grannländers suveränitet och territoriella integritet med militära medel (Hedenskog \& Persson, 2019).

Kaukasien utgör en del av denna uppfattade ryska intressesfär. Regionens geostrategiska läge mellan Kaspiska havet och Svarta havet, i skärningspunkten där den europeiska kontinenten möter Mellanöstern, har länge dragit till sig stormakternas intressen. Rysslands politiska mål i Kaukasien från Ivan IV ("den förskräcklige", 1533-1584) till Peter I (»den store», 1689-1725) var att kontrollera steppen från hoten från tatarerna och turkarna. Vad som började som en defensiv taktik förändrades dock under 1700-talet till att bli mer expansionistisk politik, att stärka imperiets närvaro vid Svarta havet för att säkra vägen ut i Medelhavet (Arakelyan, 2019). Detta sammanföll med Osmanska rikets och Persiens nedgångar. Under tre sekel hade Kaukasien utgjort en buffertzon för dessa tre angränsande imperier i deras tävlan om inflytande, men vid 1800-talets mitt hade Ryssland lagt under sig hela Kaukasien och framstod som den obestridliga stormakten i regionen.

Den ryska revolutionen och tsardömets fall 1917 ledde till att Armenien, Azerbajdzjan och Georgien de facto blev självständiga stater, men Ryssland återinförlivade dem igen redan i början av 1920-talet. Den nya sovjetmaktens kontroll i regionen, liksom tsarmaktens tidigare, upprätthölls i hög grad genom att spela ut lokala och regionala aktörer mot varandra. Gränser drogs för att hålla de olika folken i schack. Till exempel tillföll Nagorno-Karabach, huvudsakligen befolkat av armenier, den azeriska sovjetrepubliken istället för den armeniska. Stalintidens hårdföra förtryck och repression kulminerade under andra världskriget då hela folkslag i Nordkaukasien - som tjetjener, ingusjier, karatjajer och balkarer - fördrevs till Centralasien efter att ha anklagats för samarbete med tyskarna (King, 2008).

Sovjetunionens fall 1991 ledde till ett återupprättande av självständigheten för länderna i Sydkaukasien. Samtidigt öppnades regionen ånyo för inflytande från andra stater, såväl de traditionella regionala stormakterna Turkiet och Iran, som för nya aktörer i regionen som USA, EU och Kina. Ett nygammalt geopolitiskt spel tog sin början kopplat till den energirikedom som finns i Kaspiska havet. Nya olje- och gasledningar från Azerbajdzjan via Georgien till Turkiet kom att kringgå Ryssland vilket underlättade för länderna att söka andra samarbeten än med Moskva. Samtidigt blossade konflikter upp igen i regionen som legat bilagda under sovjettiden, både inom Georgien och mellan Armenien och Azerbajdzjan, vilket gav Ryssland möjligheter att återanvända taktiken att söndra och härska. Efter ett skakigt 1990tal gav de ökade oljepriserna under 2000-talet Ryssland krafter - såväl politiskt, ekonomiskt som militärt - att under Vladimir Putin mer kraftfullt och målmedvetet återetablera en rysk intressesfär i Sydkaukasien. 
Syftet med denna artikel är att påvisa hur Ryssland använder en kombination av politiska, ekonomiska och militära maktmedel för att upprätthålla en exklusiv intressesfär i regionen. Konklusionen är att Ryssland dominerar säkerhetsläget tack vare att Moskva kan lägga mer resurser på det än någon av de andra externa makterna. Ryssland är den enda externa makten som har en permanent militär närvaro i regionen. I det perspektivet står idag Armenien, Azerbajdzjan och Georgien utan egentligt alternativ till en rysk dominans. Ryssland har visat förmåga att både formulera en strategi för att påverka regionen och att genomföra denna strategi. Samtidigt finns det tillkortakommanden i den ryska strävan efter hegemoni i Sydkaukasien. Även dessa observeras i artikeln.

Artikeln delas upp i fyra avsnitt. Först kommer en översikt över vilka intressen Ryssland har i Sydkaukasien och vilka hot som Moskva ser i regionen. Nästa avsnitt ger exempel på hur Ryssland påverkar länderna politiskt och ekonomiskt, alltså med icke-militära medel. De olösta konflikterna i Georgien och Nagorno-Karabach får ett eget avsnitt i artikeln. Rysslands engagemang i konflikterna är ett sätt att säkerställa fortsatt inflytande över länderna och att motverka politik som hotar ryska intressen. Nästa avsnitt tar upp Rysslands militära styrkeposition i Sydkaukasien. I de avslutande slutsatserna diskuteras hur Ryssland kombinerar politiska och militära påtryckningar i hanterandet av sin intressesfär i Sydkaukasien.

\section{Rysslands intressen i Kaukasien och den ryska hotuppfattningen}

Den ryska militärdoktrinen från 2014 beskriver de allvarligaste militära riskerna och hoten som Ryssland står inför. Frågor som är särskilt relevanta för utvecklingen i Kaukasien är Natos utvidgning och placeringen av Nato-infrastruktur i områden som gränsar till Ryssland och upprättande av regimer i stater som gränsar till Ryssland vars politik hotar ryska intressen. Dessa betraktas alla som hot mot Ryssland (Rysslands säkerhetstråd, 2014).

Ett annat hot är kopplat till tankarna kring »färgrevolutioner», som funnit länge i Ryssland, men vidareutvecklades efter den orangea revolutionen i Ukraina 2004-05 (Hedenskog et al., 2016). I det ryska militära tänkandet betraktas "färgrevolutioner» inte som genuina uttryck för folkligt ogillande med en auktoritär regim utan som något väst organiserat i syfte att åstadkomma ett regimskifte (Hedenskog \& Persson, 2019). 2015 skrevs formuleringarna om »färgrevolutioner» för första gången in i Rysslands nationella säkerhetsstrategi och beskrevs där som ett hot mot Rysslands säkerhet (Rysslands säkerhetsråd, 2015).

I ett kaukasiskt perspektiv är det i första hand "Rosenrevolutionen» i Georgien 2003, vilken bytte ut en regim med rötter i sovjeteran mot en regering med stark orientering mot väst, som avses. På senare år ledde även protesterna i Jerevan 2015, \#ElectricYerevan, mot en kraftig höjning av gaspriset till att flera höga ryska företrädare, även utrikesminister Sergej Lavrov, varnade för en ny "färgrevolution» (Heritage \& Mkrtchyan, 2015). Men protesterna var i praktiken ledarlösa och hade 
ingen riktig udd riktad mot Ryssland. Även om farhågor från Ryssland initialt också fanns i samband med "Sammetsrevolutionen" tre år senare, vilken faktiskt ledde till ett maktskifte, var de ryska reaktionerna som helhet mer återhållsamma den gången. Maktskiftet bedömdes inte utgöra ett allvarligt hot mot det ryska inflytandet i Armenien (Barbashin \& Souleimanov, 2018).

Rysslands intresse för Sydkaukasien ligger också i att regionen är scenen för flera av de olösta konflikterna i det postsovjetiska området, så som den i NagornoKarabach mellan Armenien och Azerbajdzjan samt konflikterna i Abchazien och Sydossetien, som bröt sig ur Georgien med rysk hjälp. De olösta konflikterna gynnar Ryssland såtillvida att de garanterar Moskvas inflytande i de berörda länderna. Även om Georgiens utrikespolitiska mål är att bli medlem i EU och Nato, utgör de olösta konflikterna ett praktiskt hinder att nå detta mål eftersom i synnerhet Nato uttryckligen inte accepterar nya medlemmar som har olösta konflikter med sina grannar.

Ett annat skäl till Rysslands intresse för Sydkaukasien är kopplingen till det ryska Nordkaukasien, där Moskva bekämpat först tjetjensk separatism och sedan islamistisk extremism sedan 1990-talet. Konflikterna i Kaukasien är i hög grad sammanflätade. Till exempel stred frivilliga förband från Nordkaukasien tillsammans med sina etniska fränder i Abchazien och Sydossetien, uppmuntrade av Ryssland, under krigen i början av 1990-talet (Kutjuberija, 2007). Rysslands känslighet i Nordkaukasien är delvis kopplad till den etniska mångfalden där. I regionen lever mer än 50 etniska grupper, många med sina egna unika språk, kulturer och traditioner. Kopplat till detta finns en i Ryssland ofta spridd "dominoteori» enligt vilken Rysslands territoriella integritet står på spel i Nordkaukasien. Varje typ av eftergift där skulle, enligt denna teori, riskera att skapa tryck från andra separatiströrelser i de företrädesvis muslimska republikerna i Volga-Ural-området, ${ }^{1}$ i hjärtat av Ryssland.

Nordkaukasiens etniska mosaik är också en faktor som förbinder området med länderna söder om bergskedjan Stora Kaukasus, vilket också bidrar till Rysslands intresse för att dominera även Sydkaukasien. Ett potentiellt uppblossat krig i Sydkaukasien skulle riskera att spridas norrut eftersom några av folken lever på båda sidor om bergskedjan. ${ }^{2}$ Därför finns ett gammalt ryskt talesätt som säger att "den som vill kontrollera Nordkaukasien måste också kontrollera Sydkaukasien» (Hedenskog et al., 2018).

Våldet i Nordkaukasien utgör också ett permanent hot mot Georgien och Azerbajdzjan. Militanta islamister har periodvis tagit sig över gränsen till länderna, där det finns små fickor av etniska fränder, för att använda dessa territorier som säkra hamnar. Regeringarna i Tbilisi och Baku har då hamnat i ett dilemma: Antingen gör de ingenting och riskerar en konfrontation med Ryssland, som kan använda

\footnotetext{
${ }^{1}$ Huvudsakligen Tatarstan och Basjkortostan.

${ }^{2}$ Detta gäller främst avarer, azerier och lezginer i Dagestan och Azerbajdzjan, samt osseter i Nordrespektive och Sydossetien (Georgien).
} 
närvaron av militanta extremister från Ryssland som förevändning för intervention. Eller så riskerar de en konflikt med etniska minoriteter som bor i gränsområdena med ursprung i Tjetjenien eller Dagestan (Weiss, 2019; Civil.Ge, 2012). ${ }^{3}$

Slutligen spelar regionens närhet till Mellanöstern och de senaste krigen i Syrien och Irak en allt viktigare roll i Kaukasien. Sedan 2014, då Islamiska staten (IS) förklarade Kaukasien som en prioriterad region och intressesfär, har frågan om militanta jihadisters resor från Kaukasien till krigen i Mellanöstern och riskerna med deras eventuella återvändanden legat högt på dagordningen för politiker och säkerhetstjänster i både Ryssland och de sydkaukasiska länderna (Hedenskog, 2020).

\section{Ryska påverkansmöjligheter på länderna i Sydkaukasien}

Ryssland har olika medel - såväl militära som politiska och ekonomiska - att påverka de sydkaukasiska länderna. Det främsta är kontrollen över de olösta konflikterna som beskrivs mer utförligt i nästa avsnitt. Länderna bär också i olika hög grad på ett ryskt och sovjetiskt arv i form av ryska språket och kulturen, mellanfolkliga kontakter, media etc. Länderna har också sin beskärda del av gästarbetare i Ryssland, vilkas remitteringar i olika hög grad har betydelse för deras ekonomier.

Armenien, Azerbajdzjan och Georgien har valt olika vägar att bemöta den ryska påverkan beroende på graden av beroende av Ryssland. Armenien har valt att liera sig med Ryssland. Azerbajdzjans egna inkomster från export av energi har gjort det möjligt att balansera det ryska inflytandet, även om landet på senare tid har närmat sig Ryssland. Georgiens politiska ledning har valt en mer konfrontatorisk politik gentemot Ryssland med medlemskap i Nato och EU som mål, vilket har lett till periodvis fientliga relationer med Moskva.

Det finns också tillkortakommanden i Rysslands strävan till regional hegemoni i Sydkaukasien. Det sovjetiska kulturella och språkliga arvet blir tunnare för varje generation. Flera forskare (Rutland \& Kazantsev, 2016; Gerrits \& Bader, 2016) lyfter fram att Ryssland har institutionella problem med mjuk makt (soft power). Till exempel har inte Moskva lyckats särskilt bra med att ta till vara den moderna arbetskraftsinvandringen som en källa till mjuk makt. Tvärtom betraktar de ryska myndigheterna gästarbetarna ofta som en källa till ekonomisk och säkerhetsmässig risk snarare än som en grogrund till ryskt inflytande i deras hemländer.

\footnotetext{
${ }^{3}$ Som ett exempel på hur konflikterna i Kaukasien är gränsöverskridande och det dilemma som framför allt Georgien står inför kan nämnas den så kallade Lopota-incidenten. Det var i augusti 2012 som en grupp militanta jihadister, varav flera ryska medborgare hemmahörande i Nordkaukasien, tog sig in i Lopotadalen i norra Georgien. Därifrån försökte de sedan ta sig illegalt över gränsen till den ryska republiken Dagestan. I den skottlossning som utbröt dog 14 personer, både islamister och personer ur de georgiska specialstyrkorna. Georgiens dåvarande president, Mikheil Saakashvili, ansåg att incidenten var en provokation för att driva fram en konfrontation mellan Moskva och Tbilisi, syftande till att ge Ryssland en förevändning att gå in med trupper och ockupera mer georgiskt territorium.
} 


\section{4 | JAKOB HEDENSKOG}

\section{Rysk påverkan på Armenien}

Armenien har rätteligen kommit att betraktas som Rysslands främsta partner i regionen. Det "strategiska partnerskapet» har institutionaliserats genom Armeniens medlemskap i Collective Security Treaty Organization (CSTO) och Euroasiatiska ekonomiska unionen (EAEU) samt genom bilaterala avtal. Ryska gränstrupper från Federala säkerhetstjänsten (FSB) patrullerar Armeniens gränser till Turkiet och Iran tillsammans med armeniska gränstrupper. Ryssland har också en militärbas $i$ Gyumri i nordvästra Armenien. De två staterna har ett gemensamt luftförsvar och, sedan 2016, en gemensam militär enhet. Det finns också en gemensam regional insatsstyrka inom ramen för CSTO. Ryssland är därtill Armeniens främsta leverantör av vapen.

Enligt Tolstrup (2009) framstår Armenien som ett typexempel på hur Ryssland tagit över ett annat lands ekonomiska infrastruktur. Sedan 2002 har Moskva pressat den armeniska regeringen att lämna över kontrollen över sina strategiska tillgångar såsom vattenkraftverk, kärnkraftverk och järnvägar. Armenien är också närmast helt beroende av rysk energi. Gazprom Armenia, som äger det armeniska gasdistributionsnätet, är till 100 procent ägt av det ryska statliga bolaget Gazprom. En tioprocentig höjning av gaspriset genomfördes senast i början av 2019 (Poghosyan, 2019b). Armenien domineras därför av stora ryska affärsintressen och cirka 50 procent av alla utländska investeringar i Armeniens ekonomi kommer från Ryssland (Trading economics, u.å.). 2017 stod armeniska gästarbetare i Ryssland för över 900 miljoner USD i remitteringar, vilket motsvarade över 60 procent av alla remitteringar till Armenien (Danielyan, 2018). Sammantaget är det svårt att se att Armenien skulle kunna sluta några stora avtal med andra stater som skulle kunna gå emot Rysslands intressen.

En ytterligare omständighet som stärker det ryska inflytandet över Armenien är den isolering av landet som konflikten i Nagorno-Karabach har lett till. Armenien, som den ekonomiskt och militärt svagare parten i konflikten, saknar dessutom diplomatiska förbindelser med två av sina grannländer, Azerbajdzjan och Turkiet. Detta tvingar landet att binda upp sin säkerhet till Ryssland. En potentiell lösning av konflikten i Nagorno-Karabach skulle med ens kunna öppna upp den stora turkiska marknaden för Armenien och på sikt minska dess beroende av Ryssland, vilket bedöms vara ett av skälen till Rysslands bristande vilja att lösa konflikten. Armenien har också försökt att utöka det ekonomiska utbytet med Iran, inte minst för att importera gas, men detta har mest nått symboliska nivåer. Ryssland vill inte inbjuda till konkurrens på energiområdet. Osäkerheter kring utvecklingen i Iran, spänningen generellt kring Persiska viken samt de amerikanska sanktionerna mot Iran gör denna väg svår för Armenien (Hedenskog et al., 2018).

2013 tvingades Armenien efter påtryckningar från Ryssland att avstå från att underteckna ett associeringsavtal med EU och istället, från och med 2015, ansluta sig till EAEU tillsammans med Ryssland, Belarus, Kazakstan och 
Kirgizistan. Att Ryssland 2017 ändå tillät Armenien att underteckna ett avtal med EU - Comprehensive and Enhanced Partnership Agreement (CEPA) - visade dock att en viss diversifiering av Armeniens utrikespolitik kunde tillåtas (Hedenskog et al., 2018). Medlemskapet i EAEU hade vid den tidpunkten förmodligen avdramatiserat frågan och Ryssland såg inga risker för sitt fortsatta inflytande över Armenien.

Fundamenten i de rysk-armeniska relationerna ändrades inte heller efter maktskiftet i samband med »Sammetsrevolutionen» 2018, då oppositionsledaren Nikol Pashinyan kom till makten. Detta trots det ryska ledarskapets normalt misstänksamma attityd till politiker som kommer till makten via folkliga protester och revolutioner (Poghosyan, 2019a). Förklaringen är återigen Nagorno-Karabach och det gemensamma azerisk-turkiska trycket på Armenien. Eftersom Armenien är ett land som lever under ett konstant hot om aggression har man inte råd med att ruinera sina relationer med Ryssland utan att kompensera för det säkerhetsvakuum som skulle uppstå. Eftersom varken USA eller EU eller någon annan makt i dagsläget kan tillhandahålla någon form av säkerhetsgarantier för Armenien så återstår bara Ryssland.

\section{Rysk påverkan på Azerbajdzjan}

Azerbajdzjan har tack vare sin energirikedom lyckats föra en mer balanserad utrikespolitik. Landet exporterar olja och gas från egna källor i Kaspiska havet till EU utan att gå via ryskt territorium. Azerbajdzjan har dock en stark bilateral relation med Ryssland, men har undvikit att bli medlem i CSTO och EAEU eftersom Armenien redan är det. Ett medlemskap i CSTO skulle tekniskt sett innebära att Baku gick in i en allians med fienden och det land som ockuperar azerbajdzjanskt territorium.

Medlemskap i Nato och EU har inte heller varit aktuellt - även om landet är anslutet till EU:s Östliga partnerskap - på grund av Bryssels kritik mot bristerna i mänskliga rättigheter i Azerbajdzjan. Istället är Azerbajdzjan medlem i Alliansfria rörelsen (Non-Aligned Movement, NAM) och odlar sin starka bilaterala relation med Turkiet som delvis fungerar som en motvikt till Ryssland (Hedenskog et al., 2018). På senare år, i synnerhet efter Rysslands annektering av Krim 2014, har dock det azerbajdzjanska ledarskapet slagit in på en mer ryskvänlig väg.

Azerbajdzjans stora beroende av energiexport och bristande ekonomiska och politiska reformer har lett till att landet är beroende av konstant höga oljepriser. Skulle Azerbajdzjan drabbas av ekonomisk kollaps skulle Rysslands inflytande sannolikt öka ytterligare. Rent ekonomiskt samarbete med Ryssland inom EAEU skulle då bli attraktivare för Azerbajdzjan. Baku behöver en stabil visumfri regim för sina medborgare till Ryssland, bättre förutsättningar för de mer än en miljon azerbajdzjanska gästarbetarna där och en säker tillgång till den ryska jordbruksmarknaden. Detta har lett till att det azerbajdzjanska ledarskapet, från att ha varit direkt avvisande, under senare år mer och mer har kommit att anamma idén om ett möjligt medlemskap i EAEU. Argumentet har varit att ett närmande till Ryssland skulle 
kunna göra Moskva mer aktivt att lösa konflikten i Nagorno-Karabach. Av samma skäl började Azerbajdzjan investera i ryska vapen och öka sitt ekonomiska samarbete med Moskva. "Sammetsrevolutionen» i Armenien vid samma tidpunkt gav Moskva ett tillfälle att försöka sätta ytterligare press på Jerevan genom att närma sig Baku (Shiriyev, 2019).

Ett azerbajdzjanskt medlemskap i EAEU skulle dock förmodligen vara möjligt bara under vissa omständigheter. Om EAEU, till exempel, skulle inkludera även andra länder utanför det postsovjetiska området skulle det förändra uppfattningen om det som ett ryskkontrollerat block eller reinkarnation av Sovjetunionen. Om Turkiet därtill skulle ingå en tullunion med EAEU skulle det göra den azerbajdzjanska eliten och befolkningen mer positiva till ett medlemskap, vilket skulle kunna ses som en garant för azerbajdzjanska intressen.

\section{Rysk påverkan på Georgien}

Som framgår i tidigare avsnitt uppfattar Ryssland Natos agerande i sitt närområde och "färgrevolutioner» som hot mot Rysslands säkerhet. Ur ett ryskt perspektiv utgör därför Georgien en större utmaning för Ryssland än Armenien och Azerbajdzjan. Trots att Moskva har utnyttjat separatism i Sydossetien och Abchazien i syfte att påverka Tbilisi att ge efter för Rysslands krav sedan början av 1990-talet, innebar kriget 2008 och det ryska erkännandet av "självständigheterna» att Ryssland gick ett steg längre. De olösta konflikterna och det faktum att Ryssland de facto ockuperar 20 procent av Georgiens territorium utgör därför Rysslands främsta påtryckningsmedel på Georgien (Hedenskog et al., 2018).

Regeringen under partiet Georgisk dröm - demokratiska Georgien (GDDG), grundat av miljardären Bidzina Ivanishvili, som styrt landet sedan 2012, lyckades inledningsvis normalisera de frostiga relationerna något. Ryssland upphörde med bojkotten av georgiska viner och mineralvatten som hade gällt sedan 2006. Handel, investeringar och turism ökade kraftigt. Däremot vek inte Ryssland en tum i frågan om de olösta konflikterna utan ökade tvärtom efter 2014 sin militarisering av Sydossetien och Abchazien.

Under 2019 inträffade en akut kris i relationerna mellan Tbilisi och Moskva på grund av stora antiryska demonstrationer utanför den georgiska parlamentsbyggnaden i Tbilisi i protest mot att en rysk nationalistisk politiker tillåtits framträda från talmansstolen under en konferens för religiöst ortodoxa parlamentariker (Civil.Ge, 2019). De våldsamma protesterna ledde till att president Putin lät införa stopp på direktflyg från Ryssland till Georgien, "för att skydda ryska medborgare", till stor skada för den georgiska turistindustrin (Ellyat, 2019). Den georgiska ortodoxa kyrkan har stort inflytande och erhåller respekt i det georgiska samhället. Att den delar samma världssyn som den ryska ortodoxa kyrkan gör den känslig för exploatering av Rysslands mjuka makt i Georgien genom att sprida antivästlig och prorysk propaganda (Författarens intervjuer, Tbilisi 2017). Den georgiska ortodoxa kyrkan har 
i likhet med den ryska ortodoxa kyrkan till exempel inte erkänt självständigheten för den ortodoxa kyrkan i Ukraina från Moskvapatriarkatet.

Georgiens konfliktfyllda relation med Ryssland har gjort att landet har försökt diversifiera sin ekonomi. 2016 trädde ett frihandelsavtal med EU i kraft och året därpå visumfrihet, båda inom ramen för det associeringsavtal som slöts med EU 2014. Georgiens ekonomiska beroende av Ryssland är därför betydligt mindre än Armeniens, men det finns ändå sårbarheter kopplade till investeringar, handel, energi och remitteringar (Kapanadze, 2014). Georgien importerar dock det mesta av sin energi (86 \%) från Azerbajdzjan (Azerbaycan24.com, 2019).

Georgiens integration i Nato och EU har i dagsläget nått sin fulla potential och medlemskap finns fortfarande inte på agendan. Trots detta är det fortsatta stödet från den georgiska befolkningen för den provästliga politiken högt. Likväl finns det ett proryskt parti, Allians av patrioter, i det georgiska parlamentet. Ryssland kan förväntas använda sig av detta och andra proryska politiker som förre talmannen Nino Burjanadze, liksom av den georgiska ortodoxa kyrkan, i syfte att öka sitt inflytande, till exempel inför det kommande presidentvalet i oktober 2020.

\section{Rysslands användning av de olösta konflikterna}

Rysslands främsta påtryckningsmedel mot de sydkaukasiska länderna är Moskvas kontroll, genom sina tredubbla roller, över de olösta konflikterna: Trots att Ryssland egentligen är part i konflikterna i Georgien, så hävdar sig Moskva samtidigt vara medlare och främste garant för säkerheten. Det primära målet för Ryssland med de olösta konflikterna i Sydkaukasien är att hålla de drabbade grannländerna i ett tillstånd av instabilitet och utsatthet. Moskva förlitar sig på sin militära närvaro i Sydossetien och Abchazien, där Ryssland har militärbaser och vars "gränser» till Georgien patrulleras av ryska gränstrupper (Hedenskog et al., 2018).

Moskva har också utfärdat pass till invånarna i de georgiska separatistområdena och därmed lagt en solid grund för en eventuell militär intervention och direkt inblandning i konflikterna (Souleimanov et el., 2018). Det ryska inflytandet är störst i Sydossetien, något mer begränsat men ökande i Abchazien och svagast i NagornoKarabach. Ryssland har inga trupper på marken i Nagorno-Karabach och delar inga gränser med konfliktzonen. Dess förmåga att kontrollera vad som sker på marken i Nagorno-Karabach är begränsad. Moskvas kontroll är alltså minst i den konflikt som medför de största säkerhetsriskerna för regionen.

\section{Konflikten mellan Armenien och Azerbajdzjan om Nagorno-Karabach}

Nagorno-Karabach-konflikten med i genomsnitt några dussintals dödsfall årligen är långt ifrån den "frusna» konflikt den ofta benämns som. Dess explosiva potential visades genom upptrappningen i april 2016, vilken orsakade mer än 100 dödsoffer på båda sidor under fyra dagar (Uppsala Conflict Data Program, u.å.). Både 
Armenien och Azerbajdzjan hävdar starka band till regionen och förklarar NagornoKarabach som nationens kulturella födelseort. Båda sidor hävdar starka princippositioner: Armenien principen om nationellt självbestämmande, Azerbajdzjan principen om territoriell integritet. Det är högst osannolikt att parterna skulle överge dessa principer, om inte annat så av inrikespolitiska skäl.

Ryssland är fortfarande den mest inflytelserika externa aktören i konflikten, men dess roll är komplex. Ryssland har en informell roll som primus inter pares $\mathrm{i}$ Minskgruppen under Organisationen för säkerhet och samarbete i Europa (OSSE) som medordförande tillsammans med USA och Frankrike. Men Moskva förbereder vanligtvis sina initiativ på egen hand och involverar gruppens andra två medordförandeländer bara i sista minuten. Detta verkar dock passa både Washington och Paris, som inte har så mycket substans att tillföra till Moskvas initiativ (Författarens intervjuer i Jerevan, 2017).

Trots att båda parter - Armenien och Azerbajdzjan - har goda relationer med Ryssland misstror man Rysslands avsikter. Man uppfattar att Moskva spelar ut parterna mot varandra beroende på vilken av dem som för stunden är bättre i stånd att stärka Rysslands strategiska mål i regionen. Dessa mål inkluderar att skydda sina egna gränser, inklusive det instabila Nordkaukasien, och förhindra en ökad militär aktivitet $\mathrm{i}$ en region mellan Ryssland och Mellanöstern, där Ryssland blir alltmer involverad militärt. Som ett resultat ifrågasätter Armenien och Azerbajdzjan Rysslands intresse för att lösa konflikten i Nagorno-Karabach och kritiserar Moskvas alltför transaktionella strategi. Frånvaron av proaktivt västerländskt deltagande har emellertid lämnat de två parterna utan egentligt alternativ till en ryskdominerad medling (Hedenskog et al., 2018).

En skillnad nu jämfört med kriget 1991-94 är att båda sidor har kraftigare beväpning såsom stridsvagnar, artilleri och luftförsvar. Detta kommer sig av att Ryssland, bortsett från sina medlingsinsatser, också är den viktigaste vapenleverantören till både Azerbajdzjan och Armenien. Enligt Stockholms internationella fredsforskningsinstitut (SIPRI, u.å.) var Bakus försvarsbudget 2018 1,7 miljarder USD, vilket motsvarade 3,8 procent av bruttonationalprodukten (BNP). 80 procent av vapnen som Azerbajdzjan köpte hade ryskt ursprung (Arakelyan, 2019). Armeniens försvarsbudget var betydligt mindre i reda pengar, 609 miljoner USD, alltså en dryg tredjedel av Azerbajdzjans. Däremot utgjorde försvarsanslagen en större andel av den egna BNP $(4,8 \%)$ (SIPRI, u.å.). Armenien får köpa ryska vapen till rabatterade priser tack vare sitt medlemskap i CSTO, medan Azerbajdzjan måste betala marknadspris för sina ryska leveranser. Den ryska vapenförsäliningen till Azerbajdzjan har ökat misstron mot Ryssland i Armenien, som fruktar att armenier kan komma att dödas av ryska vapen.

Vissa observatörer misstänker en rysk roll i utbrottet av fyradagarskriget i april 2016. Tidpunkten för eskalationen tycktes vara noga planerad. När sammanstötningarna började, den 2 april, var varken Azerbajdzjans president Ilham Aliyev eller Armeniens dåvarande president Sergh Sargsyan hemma i sina länder. Istället var de 
på väg hem från toppmötet om kärnvapensäkerhet i Washington, DC, en konferens som den ryske presidenten inte deltog i. Den 1 april hade de båda presidenterna haft separata möten i Washington med vicepresidenten Joe Biden, som bekräftat USA:s roll i medlingen av konflikten över Nagorno-Karabach. Tidpunkten för upptrappningen, dagen efter dessa möten, verkade vara utvald för att undergräva just den idén. Genom att förmedla vapenvilan den 5 april, visade sig Moskva också villigt att lösa konflikten på egna villkor, genom att undvika de andra medordförandena i Minskgruppen. Således kunde Moskva både låta eskalationen bryta ut och sedan stoppa den (Hedenskog et al., 2018). Detta skickade starka signaler till parterna: För Jerevan var signalen att Azerbajdzjan är starkt och skulle kunna återta NagornoKarabach om det inte vore för Rysslands stöd till Armenien. Till Baku var signalen att även om Azerbajdzjan är starkare än Armenien, kommer Ryssland inte att tillåta Azerbajdzjan att använda sin militära styrka mot Armenien utan ryskt medgivande (Författarens intervjuer i Baku, 2017).

Trots att Jerevan och Baku är djupt oense över konflikten som sådan, förenas parterna ändå i en gemensam misstro mot Rysslands avsikter. De ser Ryssland som främst intresserad av att utöka sin militära närvaro i regionen genom en önskan att utplacera fredsbevarande trupper i konfliktzonen, något som Ryssland föreslagit flera gånger, senast i samband med den så kallade Lavrov-planen 2015 (ICG, 2019). Detta förslag har avvisats av båda parter av rädsla för att en sådan militär närvaro skulle göra dem ännu mer beroende av Moskvas skiftande intressen. Parterna fruktar ett scenario där Ryssland använder en incident som förevändning för att ingripa i konflikten, vilket skulle kunna bli inledningen till en permanent rysk militär närvaro i Nagorno-Karabach (Hedenskog et al., 2018).

\section{Konflikterna i Georgien}

Sedan Ryssland efter kriget mot Georgien 2008 erkänt Abchaziens och Sydossetiens "självständigheter», och i synnerhet efter den olagliga annekteringen av Krim 2014, har Moskva tydligt ökat sitt inflytande i separatistregionerna. Detta passar Sydossetiens önskan om förening med Ryssland, ${ }^{4}$ vilken Moskva dock inte beviljat (Hedenskog et al., 2018). Moskva har genom åren haft svårare att undvika politisk instabilitet i Abchazien, den större och folkrikare av de två separatistrepublikerna. I början av 2020 avgick "presidenten» Raul Khajimba efter folkliga protester. Han hade installerats 2014 som en följd av ett direkt ingripande från Moskva (Scollon, 2020). Båda regionerna är ekonomiskt, politiskt och militärt helt underordnade Moskva.

Ryssland har cementerat sitt inflytande i separatistterritorierna genom formella avtal. 2014 upprättades ett avtal med Abchazien om allians och strategiskt

\footnotetext{
${ }^{4} 2017$ döptes Sydossetien om till "Republiken Sydossetien - Staten Alanien», ett symboliskt steg mot separatisternas önskan om återförening med den ryska Republiken Nordossetien-Alanien.
} 
partnerskap och 2015 med Sydossetien om allians och integration. Genom att formellt erkänna Abchaziens och Sydossetiens "självständigheter», men samtidigt integrera dem politiskt, ekonomiskt och militärt i Ryssland kan Moskva använda dem som hävstång i förhållande till Tbilisi, något som skulle vara förverkat vid en formell annektering.

Den internationella medlingen för de olösta konflikterna i Georgien sker sedan oktober 2008 inom ramen för Genèvesamtalen under ledning av OSSE, EU och FN. ${ }^{5}$ En av de viktigaste frågorna har rört åtaganden om icke-våld som metod för konfliktlösning. Georgien gav ett sådant ensidigt löfte redan 2010 och har sedan dess insisterat på att Ryssland ska göra detsamma. Den ryska regeringen vägrar dock att göra detta utan hävdar att den inte är part i konflikterna. Istället vill Ryssland att Georgien undertecknar fördrag direkt med Abchazien och Sydossetien, vilket Tbilisi vägrar med hänsyn till att enheterna ingår i Georgien som är en suverän stat (Hedenskog et al., 2018).

En annan viktig källa till oenighet är frågan om återvändande av internflyktingar, mestadels etniska georgier, som representanterna för Abchazien och Sydossetien, med ryskt stöd, vägrar att diskutera. Detta ämne inkluderar frågor om undervisningsspråk i skolor i övervägande etniska georgiska områden i Abchazien, rörelsefrihet, saknade människor samt miljö- och kulturarv. En annan fråga som vuxit på senare år att den om »borderization». De ryska gränstrupperna under FSB har åtskilliga gånger flyttat eller cementerat de administrativa skiljelinjerna mellan Sydossetien och resten av Georgien. Detta har inneburit att lokala bönder plötsligt funnit att deras ägor hamnat på territorier kontrollerade av Ryssland. Enligt uppgifter från experter i området använder Ryssland gamla sovjetiska militära kartor i syfte att försöka återställa en tidigare administrativ gräns som också är lättare att försvara (Författarens intervjuer i Tbilisi, 2017).

Andra georgiska territorier med potential att vålla problem mellan Ryssland och Georgien rör framför allt situationen i Pankisidalen i Stora Kaukasus-bergen. Under det andra Tjetjenienkriget (1999-2000) och den efterföljande nio år långa antiterroristoperationen i Tjetjenien kritiserade Moskva Tbilisi för att tillåta att tjetjenska krigare använde detta område som en säker fristad. Området bebos av kisterna, en liten (ca 8000) befolkningsgrupp som tillhör Vajnach-folken tillsammans med tjetjener och ingusjier. I början av 2000-talet genomförde Ryssland flera bombningsattacker i området som riktade sig mot tjetjenska krigare och satte politiska påtryckningar på Georgien. Efter terrorattackerna i USA den 11 september 2001 bjöd Tbilisi in

${ }^{5}$ Förutom de internationellt mäklade Genèvesamtalen har Ryssland och Georgien alltsedan 2012 också ett bilateralt format för samtal. För Georgien deltar premiärministerns särskilda representant för relationerna med Ryssland Zurab Abashidze. Rysslands representant är Grigorij Karasin, fram till september 2019 statssekreterare vid utrikesministeriet och numera ledamoten av det ryska parlamentets överhus, Federationsrådet. De två brukar träffas i Prag, därför ofta kallat Pragformatet, för att diskutera framför allt handel, ekonomi, kultur och liknande. 
amerikanska trupper att utbilda georgiska antiterroriststyrkor för att rensa upp i Pankisidalen. Även om situationen där gradvis stabiliserades i takt med situationen i Tjetjenien har en inte obetydlig andel av de "tjetjenska» jihadisterna som stridit för IS i Syrien och Irak i själva verket utgjorts av kister hemmahörande i Pankisidalen (Hedenskog, 2020). ${ }^{6}$

\section{Rysslands militära styrkepositionering i Sydkaukasien}

Rysslands södra militärdistrikt (MD) baseras på det tidigare nordkaukasiska MD. Detta hade i sin tur sitt ursprung i två före detta sovjetiska militärdistrikt; dels det transkaukasiska MD som omfattade ungefär de armeniska, azeriska och georgiska sovjetrepublikernas territorier, dels det (sovjetiska) nordkaukasiska MD, som tillhörde den ryska sovjetrepubliken. Efter Sovjetunionens sammanbrott kom de sovjetiska styrkorna antingen att utgöra grunden för de nyuppsatta väpnade styrkorna i de nya staterna eller att dras tillbaka till det nordkaukasiska MD på andra sidan Stora Kaukasus. 2010 ändrades benämningen på det nordkaukasiska MD till det södra MD. Från Kaspiska havet sträcker sig dess södra gräns längs Rysslands nationella gräns med Azerbajdzjan och Georgien till Svarta havet. I sydväst sträcker det sig längs Rysslands svartahavskust och Azovska sjön, västerut längs gränsen till Ukraina och inkluderar det olagligt annekterade Krim.

Under krigstid är det troligt att andra ryska styrkor som inrikestrupper och FSB:s gränstrupper underordnas de väpnade styrkorna. Dessa är de militära styrkorna som är tillgängliga för operationer i Rysslands potentiella södra krigsskådeplats, ${ }^{7}$ som täcker Nordkaukasien och tre andra oroliga regioner: Sydkaukasien (inklusive Kaspiska havet), Mellanöstern och Svartahavsområdet, inklusive Ukraina (Hedenskog et al., 2018).

Södra militärdistriktet är också ansvarigt för tre militärbaser (MB) av brigadstorlek: I Abchazien (7:e MB), Sydossetien (4:e MB) och Armenien (102:a MB). De två ryska militära baserna i Georgien har också materiel som överskrider kraven för deras nominella brigadstorlek, det vill säga 160 stridsvagnar och pansarfordon vardera.

Två observationer kan göras angående de ryska markstridskrafternas styrkestruktur i Kaukasien, inklusive de militära baserna utomlands. För det första, i händelse av ett storskaligt krig, till exempel som en del av en konfrontation med Nato, ger styrkedispositionen Ryssland möjligheter till flera försvarslinjer. De ryska styrkorna i Armenien (102:a militärbasen, inklusive 988:e luftförsvarsregementet och

\footnotetext{
${ }^{6}$ Några av dem förmodas ha nått högt upp i IS-hierarkin så som Abu Omar al-Shishani (eg. Tarkhan Batirashvili) som omnämnts av Pentagon som "IS krigsminister» och Al-Bara Shishani (eg. Cezar Tokhosashvili), som beskrivits som "vice krigsminister». Den förste omkom i strid 2016 och den andre greps i Ukraina i slutet av 2019. Även Zelimkhan Khangoshvili, den georgiske medborgaren som mördades i Berlin i augusti 2019 anklagad för terrorism och förmodat på uppdrag av FSB:s antiterroriststyrka, var av kistiskt ursprung.

${ }^{7}$ En krigsskådeplats utgör större delen av en kontinent med angränsande hav och luftrum ovan.
} 
3624:e flygbasen, plus FSB:s gränstrupper) utgör en första linje. Baserna i de georgiska regionerna Abchazien och Sydossetien under de facto rysk kontroll (7:e och 4:e $\mathrm{MB})$ plus gränstrupperna utgör en sekundär försvarslinje. Den tredje försvarslinjen är styrkorna på ryskt territorium i södra $\mathrm{MD}$ och den fjärde förstärkningen som kan tas in från andra MD i Ryssland.

För det andra kan överskottet av stridsvagnar och pansarfordon i Rysslands tre militära baser söder om bergskedjan Stora Kaukasus, som ovan nämndes, vara förlagrad utrustning för enheter som kan bemannas med personal från andra delar av Ryssland, om behovet skulle uppstå. Detta är ett pragmatiskt sätt att snabbt kunna förstärka styrkor från motsvarande en armékår till nästan två armékårer, om än med relativt svaga stödfunktioner, söder om Stora Kaukasus. Det är lättare att transportera enbart soldater än hela enheter med tillhörande utrustning. På liknande sätt har Ryssland utrustning för flera motorskyttebrigader i lager i både centrala och östra MD (Hedenskog et al., 2018).

\section{Slutsatser}

Denna artikel har visat att ett av Rysslands centrala utrikespolitiska mål är att upprätthålla en exklusiv intressesfär i sitt närområde, däribland i Sydkaukasien. Detta görs med en kombination av politiska, ekonomiska och militära påtryckningar. En av förutsättningarna för att kunna försvara sin intressesfär, om det behövs, är förmågan att kunna använda sig av militär styrka. Ofta kan politiska påtryckningar ske med ett underförstått hot om användning av militär makt. Moskvas svagheter i strävan efter regional hegemoni ligger i bristande förståelse för mjuk makt. Rysslands hårda maktresurser i regionen transformeras därför inte automatiskt till starkt inflytande.

Sydkaukasien fortsätter att vara en konfliktfylld del av Rysslands grannskap som erbjuder utmaningar. Emellertid är Ryssland den enda externa makten som har militärbaser i regionen och därför den enda som till synes är redo att kunna agera militärt där. Rysslands främsta rivaler i regionen är USA, EU och Turkiet. USA (och Nato) är engagerade i militärt samarbete med Georgien (och i betydligt mindre utsträckning även med Armenien och Azerbajdzjan) och stöder Azerbajdzjan i dess strävan att exportera energi till världsmarknaden utan att passera Ryssland. EU:s främsta mekanism för samarbete i Sydkaukasien är Östliga partnerskapet. EU:s komparativa fördel ligger framför allt på de normativa och ekonomiska områdena. Efter Rysslands aggression mot Ukraina sedan 2014 är dock viljan från väst att utmana Rysslands hegemonianspråk i dess närområde mycket lågt. Turkiet och $\mathrm{i}$ mindre utsträckning även Iran, de två historiska rivalerna till Ryssland i Kaukasien, har sina egna intressen i regionen men verkar inte heller redo att använda militär styrka för att upprätthålla dem, särskilt inte eftersom detta skulle utmana Moskva.

Vad det gäller de olösta konflikterna verkar Ryssland för närvarande nöjt med status quo. Moskva håller de nuvarande processerna igång snarare än försöker uppnå faktiska framsteg att lösa konflikterna, vilket passar dess mål att bevara det strategiska 
inflytandet i regionen. Detta talar för att de olösta konflikterna kommer att förbli olösta under en överskådlig framtid. Militärbaserna i Abchazien och Sydossetien ger Moskva både en hävstång mot Georgien och en strukturell fördel för potentiella ryska militära operationer i regionen. Dessutom förhindrar Rysslands stöd till separatistregionerna Georgiens planer för medlemskap i Nato och EU. I NagornoKarabach har Moskva sitt svagaste grepp när det gäller förmågan att påverka händelser på marken, men lyckas ändå hålla Jerevan och Baku under sitt inflytande. En fredlig lösning på konflikten skulle undergräva Armeniens och Azerbajdzjans beroende av Ryssland som säkerhetsgarant, inklusive som vapenleverantör.

Slutligen kan konstateras att den ryska militära fredstida grupperingen i Kaukasien - de väpnade styrkorna och inrikestrupperna i norr och de tre militärbaserna och FSB-gränstrupperna i söder - är överdimensionerad med tanke på den nuvarande konfliktsituationen och bristen på en motståndare som skulle kräva så stora resurser. Rysslands militära hållning i Kaukasien avser snarare en potentiell storskalig konflikt i södra krigsskådeplatsen, inklusive ett utvidgat Mellanöstern, än bara lokala konflikter i Kaukasien.

\section{Om artikeln}

Artikeln bygger i stora delar på rapporten Security in the Caucasus: Russian policy and military posture av Jakob Hedenskog, Erika Holmquist och Johan Norberg (2018). Rapporten i sin tur bygger till stor del på intervjuer med forskare, analytiker och diplomater i Jerevan, Tbilisi, Baku och Moskva. Författaren vill framföra sitt varma tack till dr Gudrun Persson och Johan Norberg, båda kollegor på FOI, för nyttiga kommentarer till denna artikel.

\section{Referenser}

Arakelyan, L. A. (2019). Caucasian chess or the greatest geopolitical tragedy of the twentieth century. I R. E. Kanet (Red.), Routledge handbook of Russian security (s. 309-320). London och New York: Routledge.

Azerbaycan24.com. (2019, 2 maj). Azerbaijani energy makes up 86\% of Georgia's total energy import this year. Hämtad 10 januari 2020 från https:/www.azerbaycan24.com/en/azerbaijani-energy-makes-up-86of-georgia-s-total-energy-import-this-year/

Barbashin, A. \& Souleimanov, E. A. (2018, 07 juni). A color revolution Russia can live with. The American Interest. Hämtad 10 januari 2020 från https:/www.the-american-interest.com/2018/06/07/a-colorrevolution-russia-can-live-with/

Civil.Ge. (2012, 31 augusti). Saakashvili speaks of provocation attempt after deadly clash at border. Civil Georgia. Hämtad 16 januari 2020 från https://old.civil.ge/eng/article.php?id=25164

Civil.Ge. (2019, 23 juni). Ruling party says Russian delegation's visit a 'mistake', Putin stops flights. Civil Georgia. Hämtad 10 januari 2020 från https://civil.ge/archives/310127

Danielyan, E. (2018, 4 januari). Migrant remittances to Armenia soar. Azatutyan. Hämtad 10 januari 2020 från https:/www.azatutyun.am/a/28954720.html

Ellyat, H. (2019, 11 juli). Tensions between Russia and Georgia are on the rise again: Here's why it matters. CNBC. Hämtad 10 januari 2020 från https://www.cnbc.com/2019/07/11/russia-and-georgia-tensionsare-rising-heres-why-and-why-it-matters.html

Gerrits, A. W. M. \& Bader, M. (2016). Russian patronage over Abkhazia and South Ossetia: Implications for conflict resolution. East European Politics, 32(3), 297-313. 


\section{JAKOB HEDENSKOG}

Hedenskog, J. (2020, mars). Russia and international cooperation on counter-terrorism: From the Chechen wars to the Syria campaign. FOI-R-4916-SE. (s. 11-38). Stockholm: FOI.

Hedenskog, J., Holmquist, E. \& Norberg, J. (2018, februari). Security in the Caucasus: Russian policy and military posture. FOI-R-4567-SE. (s. 11-75). Stockholm: FOI.

Hedenskog, J. \& Persson, G. (2019, december). Russian security policy. I F. Westerlund \& S. Oxenstierna (Red.), Russian military capability in a ten-year perspective - 2019. FOI-R-4758-SE. (s. 79-96). Stockholm: FOI.

Hedenskog, J., Persson, G. \& Vendil Pallin, C. (2016, december). Russian security policy. I G. Persson (Red.), Russian military capability in a ten-year perspective - 2016. FOI-R-4326-SE. (97-123). Stockholm: FOI.

Heritage, T. \& Mkrtchyan. H. (2015, 2 juli). Russia warns against 'color revolution' in Armenia. Reuters. Hämtad 10 januari 2020 från https://uk.reuters.com/article/uk-armenia-protest-russia/russia-warnsagainst-colour-revolution-in-armenia-idUKKCNOPC1AU20150702

ICG. (2019, 20 december). Digging out of deadlock in Nagorno-Karabakh. International Crisis Group, Europe Report No 255 (s. 1-36). Brussels: International Crisis Group.

Kapanadze, S. (2014, juni). Georgia's vulnerability to Russian pressure points. Policy memo, ECFR 106. European council on foreign relations. Hämtad 10 januari 2020 från https://www.ecfr.eu/publications/ summary/georgias_vulnerability_to_russian_pressure_points 312

King, C. (2008). The ghost of freedom: A history of the Caucasus. Oxford: Oxford University. Press.

Kutjuberija, A. (2007, 20 december). V Abchazii v organizatsiju veteranov gruzino-abchazskoj vojny vojdut dobrovoltsy s Severnogo Kavkaza. Kavkazskij Uzel. Hämtad 30 januari 2020 från https://www.kavkazuzel.eu/articles/129284/

Poghosyan, B. (2019a, 5 november). Armenia - Russia: Strange bromance. Civilnet. Hämtad 11 november 2019 från https:/www.civilnet.am/news/2019/11/05/Armenia-\%E2\%80\%93-Russia\%D6\%89-StrangeBromance/370009

Poghosyan, B. (2019b, 14 oktober). What next in Armenia-Russia relations.... Centre for Army, Conversion and Disarmament Studies. Hämtad 15 oktober 2019 från https://cacds.org.ua/?p=8008

Rutland, P. \& Kazantsev, A. (2016). The limit of Russia's 'soft power'. Fournal of Political Power, 9(3), $395-413$.

Rysslands säkerhetsråd. (2014, 25 december). Vojennaja doktrina Rossijskoj Federatsii. Utverzjdena Prezidentom Rossijskoj Federatsii 25 dekabrja 2014 g. No PR-2976. Hämtad 15 November 2018 från http://www.scrf.gov.ru/security/military/document129/

Rysslands säkerhetsråd. (2015, 31 december). Strategija natsionalnoj bezopastnosti Rossijskoj Federatsii. Ukazom Prezidenta RF, 31 dekabrja 2015 g. N 683. Hämtad 15 augusti 2019 från http://www.scrf.gov. $\mathrm{ru} /$ security/docs/document133/

Rysslands utrikesministerium. (2016, 30 november). Kontseptsija vnesjnej politiki Rossijskoj Federatsii utverzjdena Prezidentom Rossijskoj Federatsii V.V. Putinym, 30 nojabrja 2016 g. Hämtad 15 augusti 2019 från https://www.mid.ru/ru/foreign_policy/official_documents/-/asset_publisher/CptICkB6BZ29/ content/id/2542248

Scollon, M. (2020, 14 januari). Picking up the pieces of Abkhazia's political crisis. Radio Free Erope/Radio Liberty. Hämtad 15 januari 2020 från https://www.rferl.org/a/abkhazia-political-crisis-explainer/30376986.html

Shiriyev, Z. (2019, mars). Azerbaijan's relations with Russia: Closer by default? Research Paper, Russia and Eurasia Programme. London: Chatham House.

SIPRI. (u.å.). Military expenditure database. Stockholm Peace Research Institute. Hämtad 10 januari 2020 från https://www.sipri.org/databases/milex

Souleimanov, E. A., Abrahamyan, E. \& Aliyev, H. (2018). Unrecognized states as means of coercive diplomacy? Assessing the role of Abkhazia and South Ossetia in Russia's foreign policy in the South Caucasus. Southeast European and Black Sea Studies, 18(1), 73-86.

Tolstrup, J. (2009). Studying a negative external actor: Russia's management of stability and instability in the 'near abroad'. Democratization, 16(5), 922-944.

Trading Economics. (u.å.). Armenia exports to Russia. Hämtad 20 januari 2020 från https://tradingeconomics. com/armenia/exports/russia

Uppsala Conflict Data Program. (u.å.). Azerbaijan: Artsakh (Nagorno-Karabakh). Hämtad 10 januari 2020 från https://ucdp.uu.se/conflict/388

Weiss, M. (2019, 27 september). A murder in Berlin: The untold story of a Chechen 'Jihadist' turned secret agent. The Daily Beast. Hämtad 14 januari 2020 från https://www.thedailybeast.com/zelimkhankhangoshvilis-murder-in-berlin-the-untold-story-of-a-chechen-jihadist-turned-secret-agent?ref=scroll 